\title{
Problems of Implementation of National Projects: Breaking in the Period of the Pandemic and the Way Out of the Crisis
}

\author{
Submitted 06/06/20, $1^{\text {st }}$ revision 27/07/20, $2^{\text {nd }}$ revision 29/08/20, accepted 15/09/20 \\ Zyryanov Sergey M. ${ }^{1}$, Kalmykova Anastasia V. ${ }^{2}$
}

\section{Abstract:}

Purpose: The purpose of the article is to find ways out of the crisis caused by the coronavirus pandemic when implementing national projects based on a comparative analysis of measures taken in different countries.

Design/Methodology/Approach: the authors of the study rely on the methods of comparative legal studies, interpretation of legal concepts and regulatory legal acts. The authors proceed from the premise that the nature of regulatory goals and problems associated with COVID-19 in different countries also implies the possibility of using solutions that are similar in their content.

Findings: The authors conclude that large-scale economic and social projects are being implemented in many countries, while the success of such projects is determined not only and not so much by the amount of financing of the projected activities, but by the creation of an institutional and legal framework. The coronavirus pandemic has significantly slowed down the implementation of national projects in all countries of the world, however, the problems arisen are solved in different countries in different ways. The most common measure to support national projects is extra funding, which could be directed to participating companies or consumers of their products. However, solutions aimed at creating favorable conditions for doing business, as is done, for example, in the UK, deserve the highest praise.

Practical Implications: The results could be implemented into the practice of the Russian Federation and other countries in order to resume the implementation of national projects in the context of overcoming the crisis situation caused by the spread of COVID-19.

Originality/Value: The main contribution of this article is to conduct a comparative legal analysis of the regulation of national projects and measures to overcome the crisis situation, implemented in Russia, the USA, Great Britain and European countries.

Keywords: Pandemic, COVID-19, regulation, national projects, executive authorities.

JEL Code: K23, K42.

Paper type: Research article.

Acknowledgement: This study was funded according to the research project from the Plekhanov Russian University of Economics.

${ }^{I}$ The Institute of Legislation and Comparative Law under the Government of the Russian Federation; Plekhanov Russian University of Economics, Moscow, Russian Federation, ORCID 0000-0003-2592-9695, zyryanov.s@gmail.com;

${ }^{2}$ The Institute of Legislation and Comparative Law under the Government of the Russian Federation; NRU «High School of Economics», Moscow, Russian Federation, ORCID 0000-0002-2097-2996 efimova_anastasi@mail.ru; 


\section{Introduction}

Any economy at a certain stage of its development tends to slow down its growth rates. As the national prosperity increases and the general level of education associated with it increases, the requirements for entrepreneurial activity, safety and quality of products, goods, and the provision of services increase. Accordingly, the volume of legal regulation increases, stricter standards are established, state control is strengthened, and the administrative costs of business grow. The administrative state is becoming stronger (Marshaw, 1985). Individual, sometimes even quite large-scale attempts to reform the economy do not give the desired result. This is largely due to the desire to influence the mechanism of public administration, as was the case, for example, during the administrative reform of the first federal and then regional executive power in the Russian Federation in the middle and second half of the 2000s (Naryshkin and Khabrieva, 2006). Such reforms, unfortunately, lead to an even greater strengthening of the administrative state. Over time, an understanding of the need to reduce the administrative burden and provide business with greater freedom comes as a prerequisite for progressive economic development. Many countries have gone through this kind of deregulation, sometimes referred to as a regulatory guillotine (Sidak, 2002). Since the spring of 2019, a similar reform has been underway in Russia.

Another way is the creation of territorial "development centers" - the establishment of preferential regimes of entrepreneurial activity in limited areas of the state territory. And this path has its advantages, but also its disadvantages. Assessing the Russian experience accumulated in this part, it can be concluded that such zones, although they demonstrate some growth of entrepreneurial activity within their borders, do not have a noticeable effect on the economy as a whole.

A more productive solution seems to be the implementation of national projects, distributed over large socio-economic areas: digitalization of the economy and public administration; housing construction; education; healthcare; agriculture, etc. Such national projects are deployed in Russia at the present time, and all the government's forces are thrown into their implementation. Unfortunately, the Russian Federation, like the rest of the world, has faced the COVID-19 pandemic this year. The measures taken to counter the spread of the viral infection slowed down this activity to a certain extent. Resources were reoriented to other purposes. Therefore, now it is necessary to solve the problems associated with the restoration of the processes of implementation of national projects, their accelerated promotion, their use as a locomotive for the entire economy of the country.

The purpose of this article is to find solutions to accelerate the recovery of the pace of implementation of national projects. This goal includes the following tasks:

- to reveal the essence of national projects, to clarify their goals and objectives; 
- to analyze similar campaigns in foreign countries;

- compare the response of different countries to the COVID-19 problem;

- to assess the impact of the pandemic on economic development and the implementation of national projects.

The object of the study is the situation in the implementation of national projects in connection with the coronavirus pandemic. The subject of the research is the legal and institutional framework for the implementation of national projects in the context of overcoming the COVID-19 crisis.

\section{National Projects in Russian Public Administration Practice}

In the Russian Federation, national projects have been implemented since 2004, although the first steps towards national projects were made already in 1995. Currently, 13 national projects have been launched: Health, Demography, Ecology, Housing and Urban Environment, Science, Digital Economy, Labor Productivity and Employment Support, Small and Medium Enterprises, International Cooperation and Export, Safe and Quality Highways, Culture, Education, Comprehensive plan for the modernization and expansion of the trunk infrastructure.

In order to implement national projects, an organizational structure has been formed, headed by the Presidium of the Council under the President of the Russian Federation. The organizational and control functions are performed by the project committee, the project office of the Government of the Russian Federation, departmental and regional project offices, and the public expert council (Kabytov and Kalmykova, 2019). This practice of borrowing corporate management methods allows for more flexible and efficient management in the implementation of national projects.

National projects envisage the implementation of activities on a wide range: not only targeted support in the form of direct budget allocation, but also a set of systemic measures like reducing administrative barriers, creating points of growth in labor productivity, raising the skills of labor resources, creating human resources, supporting employment, stimulation through a system of grants, the introduction of digital technologies (for the national project "Labor productivity and employment support"). The national projects are based on a competitive procedure for their implementation, which ensures greater objectivity and independence of decisions. The constituent entities of the Russian Federation participating in national projects are selected on a competitive basis; state contracts are concluded on a competitive basis with direct executors.

Due to the coronavirus pandemic, the implementation of national projects in Russia has slowed down significantly and has completely stopped in some events. Significant financial resources were redirected to solving current problems, supporting the economy, purchasing medical equipment and medicines, building and reconstructing medical institutions. 


\section{National Projects in Foreign Countries}

In foreign practices of public administration, the concept of "project management" is used, which, presumably, comes from plans to restore the economy of the USSR in the 1930s, such as the well-known GOELRO plan known as the electrification of the country.

As in Russia, in foreign countries, similar large projects represent the centralized allocation of funds and attraction of investments from other sources aimed at solving specific economic and social problems. At the same time, a distinctive feature of the most successful countries is the presence of a special organizational structure that ensures the management of project implementation. Thus, in the UK, the Major Projects Authority (MPA) was formed, which was later merged with the Infrastructure Authority into a single Infrastructure and Projects Authority (IPA).

The IPA is the center of excellence and reports to the Chief Treasurer and the Office of the Prime Minister. Its functions are typical for a project office: draw up the Government Major Projects Portfolio; request, review and approve integrated assurance and approval plans for each major project or program; carry out assurance reviews where there is cause for concern; intervene directly, where appropriate, in the delivery of major projects that are failing by providing commercial and operational support; work with departments to build skills and expertise in projects and program management; publish an annual report on major projects.

An organized, purposeful, and planned approach to identifying priority development areas, developing national projects and ensuring their implementation is indicated by the eight-step program implemented under the National Transformation Program by the PEMANDU project office subordinate to the Government of Malaysia. The first step is to define and agree on priorities. At the initial stage, population surveys and seminars were conducted. The second step is labs and brainstorming sessions - developing solutions and making plans. In the third step, plans and decisions are made public and discussed by the public. The result is roadmaps, the publication of which marks the fourth step. In the fifth step, specific performance indicators and KPIs are determined for each minister. The sixth step is public debriefing. The seventh step is an independent audit. Finally, in the last step, the annual reports and the annual report of the Prime Minister are published.

In France, structural institutional transformations are also in the basis of project activities. For the implementation of the state program Action publique-2022, the Department for State Modernization, the Interministerial Directorate of State Transformation (DITP) and the Interministerial Directorate of Digital Technologies and State ICTs (DINSIC) were established. Their powers are defined by Decree No. 2017-1584 dated November 20, 2017. In addition, by decree No. 2017-1586 of November 20, 2017, an 
inter-ministerial committee for state transformation was established, which determines the Government's policy in the field of public transformation and ensures its implementation. National programs similar to Russian national projects are being implemented in Germany, South Africa, Singapore, India, China, Saudi Arabia and other countries.

In general, foreign practices are characterized by the institutionality of approaches and legal regulation. Thus, the standard of the Project Management Institute in the USA (PMI) - Ansi Pmi Pmbok (Project Management Body of Knowledge) Guide - 2004 Edition is presented in the "Guide to the Project Management Body of Knowledge". This Handbook summarizes the processes and areas of expertise for project management. There are nine areas: content management; integration management; cost management; time management; quality control; communications management; Staff Management; Management of risks; project contract management. Some states, for example Germany, France, Great Britain, Australia, are actively introducing national standards in the field of project management into the system of legal regulation of project management. The creation of special management structures and the special regulatory legal regulation is a general trend in the implementation of national projects in Russia and foreign countries.

\section{Ways Out of the COVID-19 Crisis}

An analysis of the measures taken by states to overcome the crisis caused by COVID19 shows various approaches: from increasing budget funding to establishing separate targeted regulation providing for preferential treatment (Grima et al., 2020; Khan et al., 2020).

In the Russian Federation, the focus was on taking financial measures. Thus, according to the national project to support small and medium-sized businesses, state support is provided in the form of subsidies for paying salaries to employees. A concessional lending program has been introduced, some taxes have been abolished, and a simplified form of tax reporting for small businesses is being introduced. The administrative burden is reduced, in particular, the intensity of control and supervisory activities is reduced, and a deregulation program ("regulatory guillotine") is being implemented. Lump sum payments to families with children played an important role in supporting the economy. Within the framework of other national projects, competitive measures are envisaged to support and develop business initiatives. For example, the national project "Digital Economy" includes a "Digital Breakthrough" contest.

In other countries (USA, Germany, etc.), in order to maintain effective demand, payments were made to all citizens. A "regulatory amnesty" has been proposed following the lifting of restrictions imposed during the pandemic. It is proposed to abolish all requirements with the exception of those that directly affect the life and health of people. The UK Cabinet Office has issued a pandemic response guide that includes three 
key issues: (1) Payment; (2) Extensions of time (and associated costs); (3) Avoidance and resolution of disputes.

In terms of payments, the Government introduced a package of financial policies for businesses and individuals to keep cash flow. The procurement policy was also reconsidered. The Government pays special attention to the timeliness of payments by state bodies for executed contracts. Due to the fact that the restrictions introduced in order to prevent the spread of diseases, and in some cases the incidence of sickness of workers caused difficulties in the fulfilment of contractual obligations, the Government provided for the possibility of extending the deadlines for the execution of contracts and covering the additional costs that have arisen in order to preserve the viability of the contracting companies.

In order to resolve disputes, a requirement is established for the priority resolution of disputes related to problems in the execution of contracts against the background of the COVID-19 pandemic, the priority use of conciliation procedures, mediation. Contracting parties are encouraged to join initiatives such as the RICS Conflict Avoidance Pledge. In addition, new procedures for expedited dispute resolution in response to an emergency have been developed: Low Value Disputes Model Adjudication Procedure developed by the Construction Industry Council and the Royal Institution of Chartered Surveyors (RICS); the Pandemic Business Dispute Resolution Service developed by the Center for Effective Dispute Resolution (CEDR) and the Chartered Institute of Arbitrators (CIArb). In addition, the Government has published a set of rules for landlords and tenants on economic recovery after the coronavirus pandemic, approved by the Corporate Insolvency and Governance Act. Provided the ability to submit unfair business practices to the Competition and Markets Authority. In order to speed up economic recovery and implement large projects, the UK government has three goals: (1) to support the restart of the economy, (2) prevent unnecessary insolvencies and (3) support the long-term viability of contracts and businesses.

The Interministerial Committee for State Transformation of France recommends as ways out of this situation: (1) to move from the same public services for all to more equitable services. It is necessary to construct a public service around the end user and his needs, and not depending on how the administration is organized; (2) organize the administration in the logic of transparency of results in order to make the citizens' view a vector of requirements and efficiency; (3) create public services involving citizens and the private sector, ensuring data openness and transparency; (4) create conditions for strengthening trust between employees and the administration, and stimulate the initiative of officials.

\section{Conclusion}


As a result of the study, it was found that the development and implementation of large state projects is a known measure of promoting economic growth. With national characteristics, such projects are implemented in various directions related to an increase in the general level of well-being, a transition to new digital technologies, and stimulation of labor productivity growth.

The coronavirus pandemic has had a critical impact on the implementation of national projects. Despite the fact that the threats associated with the spread of COVID-19 have not yet been eliminated, governments are already taking measures to restore the pace of implementation of national projects, or to extend the deadlines from completion. Moreover, as the experience of some of the most successful countries shows, such measures include not only additional budget funding, but also consulting and organizational support for companies that are direct executors of the planned activities.

\section{References:}

Coglianese, C. 2019. The Semi-Autonomus Administrative State. The Regulatory Review. Available online: https://www.theregreview.org/2019/10/07/coglianese-semi-autonomous-administrative-state/.

IG. 2020. National projects declared insolvent. Independent Gazette. Available online: https://www.finanz.ru/novosti/aktsii/kudrin-predlozhil-pravitelstvu-skorrektirovatpokazateli-nacproektov-1029011850.

Grima, S., Dalli Gonzi, R., Thalassinos, I.E. 2020. The Impact of COVID-19 on Malta and its Economy and Sustainable Strategies. Available at SSRN: https://ssrn.com/abstract=3644833 or http://dx.doi.org/10.2139/ssrn.3644833.

Kalmykova, A.V., Kabytov P.P. 2019. "Flexible" Structures of Public Administration. Journal of Russian Law, 8, 107-120.

Khan, S., Rabbani, R.M., Thalassinos, I.E., Atif, M. 2020. Corona Virus Pandemic Paving Ways to Next Generation of Learning and Teaching: Futuristic Cloud Based Educational Model. Available at SSRN: https://ssrn.com/abstract=3669832.

Mashaw, J.L. 1985. Due Process in the Administrative State. New Haven, Yale University Press, 279.

Naryshkin, S.E., Khabrieva, T.Y. 2006. Administrative reform in Russia. Scientific and Practical Guide. Moscow, Infra-M, 352.

Percival, R.V. 2001. Presidential Management of the Administrative State: The Not-So-Unitary Executive. Duke Law Journal, 3(51).

Sidak, J.G. 2002. The Failure of Good Intentions: The WorldCom Fraud and the Collapse of American Telecommunications After Deregulation. Yale Journal on Regulation, 2(20), 207-267.

Vermeule, A. 2017. Bureaucracy and Distrust: Landis, Jaffe and Kagan on the Administrative State. Harvard Law Review, available online: https://papers.ssrn.com/sol3/papers.cfm?abstract_id=2863112.

Wllofson, C. 1994. Deregulation: The Politics of Health \& Safety. Socialist Lawyer, 23, 15 18. 